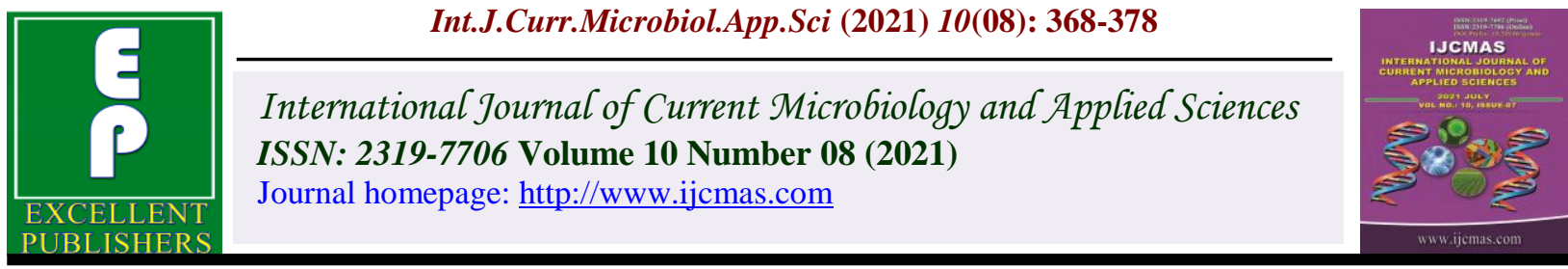

Original Research Article

https://doi.org/10.20546/ijcmas.2021.1008.045

\title{
Maternal Employment Status and Influence of Parenting Practices on Children
}

\author{
V. S. Bhalerao* and P. N. Ujagare \\ Department of HD and FS, College of Community Science, VNMKV, Parbhani, India \\ *Corresponding author
}

A B S T R A C T

Keywords

Employed mother, unemployed mother, Parenting practices, Child care

Article Info

Accepted:

20 July 2021

Available Online:

10 August 2021
The survey of total 150 employed (75) and unemployed (75) mothers having a preschool / school going children in the age range of 2 to 10 years were interviewed based on the structured and open ended interview schedule cum checklist. After collecting information on personal background, disciplinary practices adopted while upbringing their young children by employed and unemployed mothers was analysed. The statistical methods employed for this research were $\mathrm{z}$ value and correlation tests. The research indicate the significant differences between employed and unemployed mothers children in term of getting facilities and recognition of self responsibilities. The employed mothers were having more expectations from children (87\%), they were shouting at children for the misbehavior (87\%) and for mistakes they were giving some punishments too. Comparatively unemployed mothers were trying to divert child's mind in constructive activities, motivating them for their good behavior ( $97 \%$ each) trying to understand child's mistake by listening to his explanation, giving rewards to children (95\% each), setting role models to them (92\%). The highly significant differences were found in employed and unemployed mothers' experiences regarding support from the family members as husband and in laws with respect to support in managing home.

\section{Introduction}

Children of today are the citizens of tomorrow. They are like clay in the potter's hand, handled with love and care, they become something beautiful or else they would develop into problematic personality. Most of the experts consider childhood, especially from the birth through the ages of 6 , as the period for shaping a child's personality and as a foundation for his/her advancing behavior. The mother is the first socializing agent with whom child interacts more during early years. The child is dependent on mother for the basic needs hence mother plays a vital role in child upbringing. In most families, the responsibility of caring employed mothers were having more expectations from children $(87 \%)$, they were shouting at children for the misbehavior $(87 \%)$ and for mistakes they were 
giving some punishments too. Comparatively unemployed mothers were trying to divert child's mind in constructive activities, motivating them for their good behavior $(97 \%$ each) trying to understand child's mistake by listening to his explanation, giving rewards to children (95\% each), setting role models to them (92\%).spend significantly large amount of time with their children than do fathers or other family members (Harries, S. 2018). The idea that mothers are the "natural caregiver" of their children is rooted in the culture of most of the societies, specially in India.

Children's behavior is outcome of family environment where role of mother is of great importance. It has been observed that there is a difference between children of employed and unemployed mothers. The intersection of maternal employment and child care influence child's cognitive functioning, behavioral attitude, intensity and timing. Employment of mother in the first year of child's life had detrimental effects on the cognitive and behavioral development of children regardless of gender or poverty status (Baydar, N \& Gunn, J. B. (1991). It was seen that mothers role influences different traits of children regarding their adjustment, intelligence, values and behavior (Dixit, K. 2007). A mother is particularly important not because she has special skills but because she is with her child for a much greater time than any other person and her instructions reflect a very strong influence on attitudes, abilities and behavior of children. Most of the children, who are successful and well adjusted, come from homes where parental attitudes are favourable and a wholesome relationship existed between children and parents (Aeri, P. \& Jain, D. 2010). According to Craige, L. (2006), those mothers who are highly educated and working, are more sensitive to their children. Employed mothers are found to be unable to spend much more time with children. Still women are generally expected to fulfil the responsibilities all the domestic work and child care alone by themselves, hence their pre occupation with an outside job often results in the neglect of some traditional domestic responsibilities which are almost always adversely commented upon by the adjoining members of the family. Working women themselves find it difficult to carry on with the two roles concurrently and some of them are unhappy about performing the dual roles because of not having any kind of help from in-laws. As compared to employed mothers, unemployed mothers spend prolonged hours for child care; get involved in all developmental activities of their child (Sultana, A. M \& Noor, Z. 2012). Mothers make special efforts to have celebrations for their children, while employed mothers afford money and resources as compared to unemployed mothers.

The quality of mother child relationship such as sensitivity, guidance and attention are important predictors of child's overall development (Anil, M. A., Bindu, S \& Bhat, J. S. 2021). Parenting and mothers involvement in disciplinary practices has a valuable influence on child's personality and achievement. Parenting style is a psychological construct representing standard strategies that parents use for child upbringing. Baumrind's (1971) authoritative, authoritarian and permissive methods are currently widely employed techniques of disciplining. Authoritative disciplining relate to high self esteem and life satisfaction (Mayuri, K., Divya, V \& Kiran, K 2017). Authoritarian style has low responsiveness and high demanding, and finally, permissive style, which is labelled by high responsiveness and low demands on children. Parenting styles have been characterized by dimensions of parental responsiveness and demanding nature concluded by Baumrind (1991). Alizadeh, S. (2011) examined that parenting practices being too strict in childhood resulted in 
children's behavioral problems in future. Gold, D. \& Andres, D. (1978) indicated that the relationship between maternal employment and children's development varies; it depends upon aspects of development of children's sex role concepts. Maternal employment status was more strongly related to the mother's satisfaction with her role. Mc Wayne et al., (2004) noted parents who show active parental involvement seems to have a more positive effect on children's development and more active in the field of parental participation. Family environment influences academic achievement of children of working and nonworking mothers. Saini (2005) revealed that children of working mothers were more independent than children of nonworking mothers.

\section{Materials and Methods}

The survey of 150 employed and unemployed mothers having a preschool / school going children in the age range of 2 to 10 years were interviewed based on the structured and open ended interview schedule cum checklist. For considering the opinions of children about benefits perceived due to employment and unemployment of mothers, the 46 children of employed mothers and 25 children of unemployed mothers were selected purposively in the age range 8 to 10 years.After collecting information on personal background, disciplinary practices adopted while upbringing their young children by employed and unemployed mothers the data was analysed. The statistical methods employed for this research were $\mathrm{z}$ value and correlation tests.

\section{Results and Discussion}

Table 1 deals with family background information of employed and unemployed mothers. It is clear from the table that irrespective of employment of mothers, large number of families were seen to be nuclear type $(60-61 \%)$. While it was found that mostly employed mothers were belonging to small size $(53 \%)$, middle SES (73\%) families having 1-2 children $(60 \%)$ where the unemployed mothers were belonging to medium sized families (45\%), lower SES (95\%) and having 3-4 children ( $73 \%)$. With regard to age, a large majority of fathers as well as mothers (61 $91 \%$ ) were in 20-30 yrs age range, having higher secondary education (40-45\%) with mostly (90-95\%) monthly income between Rs 10,000- Rs 30,000. Sixty per cent of the mothers had less than 5 yrs experience of service ranging between working for 5-7 hours $(48 \%)$. The large percentage of fathers were involved in business like tailoring, hotel owner, medical shop, shop owner, ornament selling, milkman, vegetable vendor, mobile accessories provider etc. While 77 per cent of employed mothers were working as preschool and primary school teachers, supervisors, clerk, nurse, typist, etc

From Table 2 it is clear that 61 per cent of the employed mothers' children were hailed from 2-6 years age group, 58 per cent of them were males, were taking education in primary school (61\%), first born (44\%) and studying in semi English medium (74\%). More than fifty per cent of them were having school timings between $12.30-5.30 \mathrm{hrs}$.

In case of children of unemployed mothers, it was seen that 67 per cent of them were in the age range 2-6 years, females (59\%), attending preschool (40\%), were first born (47\%), studying in vernacular language i.e. Marathi $(37 \%)$ and their school timings were 9.0012.00 noon. It needs to be noted down that 27 per cent of the children were not attending preschools, the reason given by the unemployed mothers was due to Covid 19 pandemic situation, children were not sent to any preschool. Table 3 details on opinions of children about benefits perceived due to 
employment and unemployment of mothers. Almost all children of employed mothers reported that due to the employment of their mothers, their academic performance was good, they avail basic minimum facilities required, they get more love and affection, they were able to join extra classes for better school performances and even they recognized self responsibilities as compared to their friends. A higher percentage of employed mothers children expressed that the maternal employment inculcated good habits (89\%) among them and it was a inspiration for them to work hard in life (78\%).

The children of unemployed mothers opined that they perform well in academics as their mothers give them time to in doing school activities, they developed good habits as the mothers were accompanying them while playing or doing other various activities. A large majority of the children of unemployed mothers expressed their views on benefits of unemployment of mothers as they get more love and affection (88\%), it was an inspiration for them to work hard and keep mother happy (84\%), they joined extra classes (72\%), parents afford them all facilities $(60 \%)$ and lastly they developed responsible behavior (40\%).

The significant differences were noted between employed and unemployed mothers children in term of getting facilities and recognition of self responsibilities. The employed mothers children were excelling in both the cases. The research study of Dixit, K. (2007) was found to be compatible with the above results. Table 4 denotes various disciplinary practices adopted by the employed and unemployed mothers. With regard to employed mothers, it was reported that majority of them do not give flexibility in rules $(76 \%)$ to children and adhere to strict and fixed rules and regulations (67\%).

While those employed mothers who were following authoritative parenting style expressed that they have more expectations from children (87\%); and even for child's misbehaviour they take immediate and strict action $(80 \%)$. In case of permissive parents, almost all mothers expressed that they give punishments to children as per mistake however 86 per cent of the employed mothers accepted that they shout at children for their wrong deeds. On the other hand, a large majority of them give opportunity to their children for corrections (79\%), they make children to divert their mind into constructive activities $(73 \%)$, motivate them for good behaviour (71\%), reinforce the positive behaviour by appreciating, through a gestures (68\%), give rewards for good behaviour (59\%), for any mistake committed by child, consider their explanation and try to be role model in front them in family (54-33\%).

In case of unemployed mothers, it was compared that about 37 of them were following strict and fixed rules for the children while 60- 65 per cent of the unemployed mothers expressed that they have more expectations and they also give opportunity to their children for improving their behaviour or correcting themselves. Fifty one per cent of unemployed mothers were not giving punishments to children as per mistakes at all. 
Table.1 Family background information of sample children

\begin{tabular}{|c|c|c|c|c|}
\hline Background variables & \multicolumn{2}{|c|}{$\begin{array}{l}\text { Employed mothers } \\
\text { (75) }\end{array}$} & \multicolumn{2}{|c|}{$\begin{array}{l}\text { Unemployed mothers } \\
\text { (75) }\end{array}$} \\
\hline $\begin{array}{l}\text { Family type } \\
\text { Nuclear } \\
\text { Joint }\end{array}$ & \multicolumn{2}{|c|}{$\begin{array}{l}60.00(45) \\
40.00(30)\end{array}$} & \multicolumn{2}{|c|}{$\begin{array}{l}61.33(46) \\
38.66(29)\end{array}$} \\
\hline $\begin{array}{c}\text { Family size } \\
\text { Small }(<4) \\
\text { Medium }(4-8) \\
\text { Large }(>8)\end{array}$ & \multicolumn{2}{|c|}{$\begin{array}{l}53.33(40) \\
41.33(31) \\
04.00(04)\end{array}$} & \multicolumn{2}{|c|}{$\begin{array}{l}42.66(32) \\
45.33(34) \\
12.00(09)\end{array}$} \\
\hline $\begin{array}{l}\text { Socio-economic class } \\
\text { Middle } \\
\text { Lower }\end{array}$ & \multicolumn{2}{|c|}{$\begin{array}{l}73.33(55) \\
26.66(20)\end{array}$} & \multicolumn{2}{|c|}{$\begin{array}{c}05.33(4) \\
94.66(71)\end{array}$} \\
\hline $\begin{array}{c}\text { No. of children } \\
1-2 \\
3-4\end{array}$ & \multicolumn{2}{|c|}{$\begin{array}{l}60.00(45) \\
40.00(30)\end{array}$} & \multicolumn{2}{|c|}{$\begin{array}{l}26.66(20) \\
73.33(55)\end{array}$} \\
\hline & $\mathbf{F}$ & $\mathbf{M}$ & $\mathbf{F}$ & $\mathbf{M}$ \\
\hline $\begin{array}{c}\text { Age group (Yrs.) } \\
\mathbf{2 0 - 3 0} \\
30-40 \\
\end{array}$ & $\begin{array}{l}66.66(50) \\
33.33(25)\end{array}$ & $\begin{array}{l}70.66(53) \\
29.33(22)\end{array}$ & $\begin{array}{l}90.66(68) \\
09.33(07)\end{array}$ & $\begin{array}{l}61.33(46) \\
38.66(29)\end{array}$ \\
\hline $\begin{array}{c}\text { Education } \\
\text { SSC } \\
\text { HSC } \\
\text { Graduates } \\
\text { >Post graduation }\end{array}$ & $\begin{array}{c}38.66(29) \\
42.66(32) \\
18.66(14) \\
--\end{array}$ & $\begin{array}{l}14.66(11) \\
45.33(34) \\
29.33(22) \\
10.66(08)\end{array}$ & $\begin{array}{l}26.66(20) \\
40.00(30) \\
25.33(19) \\
08.00(06)\end{array}$ & $\begin{array}{l}-- \\
40.00(30) \\
34.66(26) \\
25.33(19)\end{array}$ \\
\hline $\begin{array}{c}\text { Monthly income (Rs.) } \\
<\mathbf{1 0 , 0 0 0} \\
\mathbf{1 0 , 0 0 0 - 3 0 , 0 0 0} \\
>\mathbf{3 0 , 0 0 0}\end{array}$ & $\begin{array}{l}05.33(04) \\
94.66(71) \\
--\end{array}$ & $\begin{array}{l}09.33(07) \\
90.66(68) \\
--\end{array}$ & $\begin{array}{l}06.66(05) \\
92.00(69) \\
01.33(01)\end{array}$ & $\begin{array}{l}-- \\
-- \\
--\end{array}$ \\
\hline $\begin{array}{c}\text { Type of employment } \\
\text { Professionals } \\
\text { Skilled workers } \\
\text { Business }\end{array}$ & $\begin{array}{l}06.00(05) \\
24.00(18) \\
69.33(52)\end{array}$ & $\begin{array}{c}77.33(58) \\
22.66(17) \\
--\end{array}$ & $\begin{array}{c}77.33(58) \\
22.66(17) \\
--\end{array}$ & $\begin{array}{l}-- \\
-- \\
--\end{array}$ \\
\hline $\begin{array}{c}\text { Employment duration (hrs.) } \\
\text { Below } 5 \\
5-7 \\
>7\end{array}$ & $\begin{array}{l}-- \\
-- \\
--\end{array}$ & $\begin{array}{l}44.00(33) \\
48.00(36) \\
08.00(06)\end{array}$ & $\begin{array}{l}-- \\
-- \\
--\end{array}$ & $\begin{array}{l}-- \\
-- \\
-\end{array}$ \\
\hline $\begin{array}{c}\text { Length of service(Yrs.) } \\
<5 \text { yrs } \\
5-10 \text { yrs } \\
>10 \text { yrs }\end{array}$ & $\begin{array}{l}-- \\
-- \\
--\end{array}$ & $\begin{array}{l}60.00(45) \\
18.66(14) \\
21.33(16)\end{array}$ & $\begin{array}{l}-- \\
-- \\
--\end{array}$ & $\begin{array}{l}-- \\
-- \\
--\end{array}$ \\
\hline
\end{tabular}

$\mathrm{F}$ - Father M - Mother Figures in parenthesis indicate frequencies 
Table.2 Personal background information of the sample children of employed and unemployed mothers

\begin{tabular}{|c|c|c|}
\hline \multirow[t]{2}{*}{ Background information of children } & \multicolumn{2}{|c|}{ Percentages of children } \\
\hline & Employed mothers (75) & Unemployed mothers( 75$)$ \\
\hline $\begin{array}{c}\text { Age (Yrs.) } \\
2-6 \\
7-10\end{array}$ & $\begin{array}{l}38.66(29) \\
61.33(46)\end{array}$ & $\begin{array}{l}66.66(50) \\
33.33(25)\end{array}$ \\
\hline $\begin{array}{l}\text { Gender } \\
\text { Male } \\
\text { Female }\end{array}$ & $\begin{array}{l}58.00(44) \\
41.00(31)\end{array}$ & $\begin{array}{l}41.33(31) \\
58.66(44)\end{array}$ \\
\hline $\begin{array}{c}\text { Education } \\
\text { Preschool } \\
\text { Primary School } \\
\text { Not attending preschool }\end{array}$ & $\begin{array}{c}38.66(29) \\
61.33(46) \\
-\end{array}$ & $\begin{array}{l}40.00(30) \\
33.33(25) \\
26.66(20)\end{array}$ \\
\hline $\begin{array}{l}\text { Ordinal position } \\
\text { First born } \\
\text { Middle born } \\
\text { Last born }\end{array}$ & $\begin{array}{l}44.00(33) \\
29.33(22) \\
26.66(20)\end{array}$ & $\begin{array}{l}46.66(35) \\
40.00(30) \\
13.33(10)\end{array}$ \\
\hline $\begin{array}{c}\text { Medium of education } \\
\text { Vernacular language } \\
\text { English } \\
\text { Semi English }\end{array}$ & $\begin{array}{l}12.00(09) \\
13.33(10) \\
74.00(56)\end{array}$ & $\begin{array}{l}37.33(28) \\
09.33(07) \\
26.66(20)\end{array}$ \\
\hline & $(n=75)$ & $(n=55)$ \\
\hline $\begin{array}{c}\text { School timings } \\
\text { 9.00-12.00 (3 hrs.) } \\
7.30-12.30 \text { (4 hrs.) } \\
\text { 12.30-5.30 (5 hrs.) }\end{array}$ & $\begin{array}{r}09.33(07) \\
36.00(27) \\
54.66(41)\end{array}$ & $\begin{array}{l}63.63(35) \\
16.36(09) \\
20.00(11)\end{array}$ \\
\hline
\end{tabular}

Figures in parenthesis indicate frequencies

Table.3 Opinions of children about benefits perceived due to employment and unemployment of mothers

\begin{tabular}{|c|c|c|c|}
\hline \multirow[b]{2}{*}{ Benefits } & \multicolumn{2}{|c|}{ Percentages of children } & \multirow[t]{2}{*}{$Z$ values } \\
\hline & $\begin{array}{c}\text { Employed } \\
\text { mothers } \\
(n=46)\end{array}$ & $\begin{array}{c}\text { Unemployed } \\
\text { mothers } \\
(n=25)\end{array}$ & \\
\hline Good academic performance & $100.0(46)$ & $100.0(46)$ & -- \\
\hline Get all facilities & $100.0(46)$ & $60.00(15)$ & $2.11 *$ \\
\hline Inculcate good habits & $89.13(41)$ & $100.0(25)$ & $0.45^{\mathrm{NS}}$ \\
\hline Inspiration for working hard & $78.26(36)$ & $84.00(21)$ & $0.28^{\mathrm{NS}}$ \\
\hline Recognized self responsibilities & $100.0(46)$ & $40.00(10)$ & $3.60^{* *}$ \\
\hline $\begin{array}{c}\text { Get more love and affection from } \\
\text { mother }\end{array}$ & $100.0(46)$ & $88.00(22)$ & $0.52^{\mathrm{NS}}$ \\
\hline Able to join extra classes & $100.0(46)$ & $72.00(18)$ & $1.36^{\mathrm{NS}}$ \\
\hline
\end{tabular}

Figures in parenthesis indicate frequencies $* \mathrm{P}<0.05$ level $* * \mathrm{P}<0.01$ level NS - Non-Significant 
Table.4 Disciplinary practices followed by employed and unemployed mothers

\begin{tabular}{|c|c|c|c|}
\hline \multirow[b]{2}{*}{ Disciplinary methods } & \multicolumn{2}{|c|}{ Percentages of children } & \multirow[b]{2}{*}{$Z$ values } \\
\hline & $\begin{array}{c}\text { Employed } \\
\text { mothers } \\
(n=75)\end{array}$ & $\begin{array}{c}\text { Unemployed } \\
\text { mothers } \\
(n=75)\end{array}$ & \\
\hline $\begin{array}{l}\text { Authoritarian method } \\
\text { Less freedom to child } \\
\text { No decisions by child } \\
\text { Strict and fixed rules and regulations } \\
\text { No flexibility in rules }\end{array}$ & $\begin{array}{l}49.33(37) \\
46.66(35) \\
66.66(50) \\
76.00(57)\end{array}$ & $\begin{array}{l}08.00(06) \\
10.66(08) \\
38.66(29) \\
05.33(04)\end{array}$ & $\begin{array}{l}7.24^{* *} \\
6.59^{* *} \\
3.17^{* *} \\
8.09^{* *}\end{array}$ \\
\hline $\begin{array}{c}\text { Authoritative method } \\
\text { Have more expectations from child } \\
\text { Set clear rules and boundaries to be followed } \\
\text { frequently } \\
\text { Give opportunities to improve } \\
\text { Immediate and strict action for child's } \\
\text { misbehavior }\end{array}$ & $\begin{array}{l}86.66(65) \\
26.66(20) \\
50.66(38) \\
80.00(60)\end{array}$ & $\begin{array}{l}60.00(45) \\
20.00(15) \\
62.66(47) \\
36.00(27)\end{array}$ & $\begin{array}{l}2.20^{*} \\
1.76^{\mathrm{NS}} \\
1.30^{\mathrm{NS}} \\
4.37^{* *}\end{array}$ \\
\hline $\begin{array}{l}\text { Permissive method } \\
\text { Less control over children } \\
\text { Punishments as per mistakes } \\
\text { Shouting of the child } \\
\text { Beating the child }\end{array}$ & $\begin{array}{l}12.00(09) \\
100.0(75) \\
86.66(65) \\
68.00(51)\end{array}$ & $\begin{array}{c}-- \\
50.66(38) \\
28.00(21) \\
14.66(11)\end{array}$ & $\begin{array}{l}-\overline{-}^{* *} \\
5.63^{* *} \\
6.81^{* *}\end{array}$ \\
\hline $\begin{array}{c}\text { Democratic method } \\
\text { Reward for good behavior } \\
\text { Motivate the child for good behavior } \\
\text { Set good examples and be the role model } \\
\text { Provide guidance and support to prevent } \\
\text { problems } \\
\text { For any mistake consider explanation from child } \\
\text { Give opportunity for correction } \\
\text { Reinforce the positive behavior } \\
\text { Diverting child's mind to constructive activities } \\
\text { Teaching children to care \& understand others }\end{array}$ & $\begin{array}{l}58.66(44) \\
70.66(53) \\
53.33(40) \\
65.33(49) \\
54.66(41) \\
78.66(59) \\
68.00(51) \\
73.33(55) \\
65.33(49)\end{array}$ & $\begin{array}{l}94.66(71) \\
97.33(73) \\
92.00(69) \\
86.66(65) \\
94.66(71) \\
85.33(64) \\
88.00(66) \\
97.33(73) \\
90.66(68)\end{array}$ & $\begin{array}{l}2.81^{* *} \\
1.93^{\mathrm{NS}} \\
3.16^{* *} \\
1.71^{\mathrm{NS}} \\
3.18^{* *} \\
0.50^{\mathrm{NS}} \\
1.56^{\mathrm{NS}} \\
1.71^{\mathrm{NS}} \\
1.97^{\mathrm{NS}}\end{array}$ \\
\hline
\end{tabular}

Figures in parenthesis indicate frequencies $\mathrm{P}^{*}<0.05$ level $* * \mathrm{P}<0.01$ level NS - Non-significant 
Table.5 Experiences of employed and unemployed mothers regarding support they get from family members

\begin{tabular}{|c|c|c|c|c|c|c|}
\hline \multirow[t]{2}{*}{ Experiences faced by mothers } & \multicolumn{2}{|c|}{ Employed mothers } & \multicolumn{2}{|c|}{ Unemployed mothers } & \multicolumn{2}{|c|}{$Z$ values } \\
\hline & $\begin{array}{l}\text { Husbands } \\
(\mathrm{n}=75) \\
\quad(\mathrm{a})\end{array}$ & $\begin{array}{c}\text { In laws } \\
(\mathbf{n}=30) \\
(\mathbf{b})\end{array}$ & $\begin{array}{l}\text { Husbands } \\
(\mathbf{n}=75) \\
\text { (d) }\end{array}$ & $\begin{array}{c}\text { In laws } \\
(\mathbf{n}=26) \\
(\mathbf{e})\end{array}$ & $\begin{array}{l}\text { Husbands } \\
(\mathbf{n}=75) \\
(\mathbf{a} \text { Vs d) }\end{array}$ & $\begin{array}{l}\text { In laws } \\
(\mathrm{n}=75) \\
(\mathrm{b} \text { Vs e })\end{array}$ \\
\hline Support in managing home & $89.33(67)$ & $10.66(08)$ & $22.66(17)$ & $53.84(14)$ & $6.30 * *$ & $4.07 * *$ \\
\hline Sharing family responsibilities & $74.66(56)$ & $14.66(11)$ & $100.0(75)$ & $19.23(05)$ & $1.76^{\mathrm{NS}}$ & $1.01^{\mathrm{NS}}$ \\
\hline $\begin{array}{c}\text { Get support in time } \\
\text { management }\end{array}$ & $76.00(57)$ & $40.00(30)$ & $17.33(13)$ & $46.15(12)$ & $6.56^{* *}$ & $0.53^{\mathrm{NS}}$ \\
\hline Appreciation for work efficiency & $96.00(72)$ & $36.00(27)$ & $20.00(15)$ & $38.46(10)$ & $6.75^{* *}$ & $0.24^{\mathrm{NS}}$ \\
\hline $\begin{array}{c}\text { Complaining about } \\
\text { inconvenience of family } \\
\text { members }\end{array}$ & $22.66(17)$ & $38.66(29)$ & $06.66(05)$ & $07.69(02)$ & $6.02 * *$ & $4.35 * *$ \\
\hline Encounter conflicts in family & $08.00(06)$ & $18.66(14)$ & $12.00(09)$ & $07.69(02)$ & $2.52 *$ & $3.04 * *$ \\
\hline No help in household chores & $24.00(18)$ & $09.33(07)$ & $85.33(64)$ & $46.15(12)$ & $6.03 * *$ & $4.04 * *$ \\
\hline Inadequacy in family expenses & $13.33(10)$ & $20.00(15)$ & $05.33(04)$ & $07.69(02)$ & $5.06^{* *}$ & $3.21 * *$ \\
\hline $\begin{array}{c}\text { Being neglected by family } \\
\text { members }\end{array}$ & $09.33(07)$ & $17.33(13)$ & $64.00(48)$ & $38.46(10)$ & $7.38 * *$ & $2.62 * *$ \\
\hline $\begin{array}{l}\text { Valued decision in family } \\
\text { matters }\end{array}$ & $74.66(56)$ & $13.33(10)$ & $56.00(42)$ & 34.61(09) & $1.74^{\mathrm{NS}}$ & $3.00 * *$ \\
\hline
\end{tabular}

Figures in parenthesis indicate frequencies ** $\mathrm{P}<0.01$ level NS - Non-significant 
Table.6 Correlation between adoption of disciplinary practices adopted for children by the mothers and selected background variables

\begin{tabular}{|c|c|c|}
\hline Background variables of children & \multicolumn{2}{|c|}{$\begin{array}{c}\text { Correlation between disciplinary practices } \\
\text { followed by employed and unemployed mother }\end{array}$} \\
\cline { 2 - 3 } & $\begin{array}{c}\text { Employed mother } \\
(\mathbf{n}=75)\end{array}$ & $\begin{array}{c}\text { Unemployed mother } \\
(\mathbf{n}=75)\end{array}$ \\
\hline Age & $-0.13^{\mathrm{NS}}$ & $-0.31^{* *}$ \\
\hline Gender & $-0.25^{*}$ & $-0.08^{\mathrm{NS}}$ \\
\hline Ordinal position & $0.04^{\mathrm{NS}}$ & $-0.06^{\mathrm{NS}}$ \\
\hline Education & $0.03^{\mathrm{NS}}$ & $-0.16^{\mathrm{NS}}$ \\
\hline Family type & $0.16^{\mathrm{NS}}$ & $-0.04^{\mathrm{NS}}$ \\
\hline Family size & $0.04^{\mathrm{NS}}$ & $0.00^{\mathrm{NS}}$ \\
\hline Monthly Income & $0.06^{\mathrm{NS}}$ & $0.15^{\mathrm{NS}}$ \\
\hline SES & $0.07^{\mathrm{NS}}$ & $0.026^{*}$ \\
\hline School timings & $0.25^{*}$ & $0.02^{\mathrm{NS}}$ \\
\hline Mother age & $-0.11^{\mathrm{NS}}$ & $-0.23^{*}$ \\
\hline Mother education & $0.09^{\mathrm{NS}}$ & $0.09^{\mathrm{NS}}$ \\
\hline Hours of employment of mothers & $0.30^{* *}$ & -- \\
\hline
\end{tabular}

A very large percentage of unemployed mothers expressed that they divert child mind towards constructive activities so as to engage them, motivate good behaviour by using good set words $(97 \%)$ or rewarding and listen to the explanation of child for any mistake $(95 \%$ each), good role models in front of children's eyes (92\%), make children to take care of others as well as try to develop understanding nature of child for others $(91 \%)$, reinforce positive behaviour among children by appreciating them or giving toffee, sweets etc, (88\%) followed by giving opportunity to children for correction in their behaviour when they

It can be said that employed mothers were having more expectations from children $(87 \%)$, they were shouting at children for the misbehavior (87\%) and for mistakes they were giving some punishments too. Comparatively unemployed mothers were trying to divert child's mind in constructive activities, motivating them for their good behavior $(97 \%$ each) trying to understand child's mistake by listening to his explanation, giving rewards to children (95\% each), setting role models to them $(92 \%)$. They were trying to teach child for caring and understanding others (91\%), reinforcing positive behavior among children. commit any mistake (55\%). Similar kind of results were seen in findings of Dixit, $\mathrm{K}$. (2007).

Table 5 deals with experiences of employed and unemployed mothers regarding support they get at family front. The large majority (74-96\%) of employed mothers opined that they receive appreciation from their husbands for their work efficiency, get support in managing household activities, for time management and even, family responsibilities being shared as well as their decisions being valued in family matters. While 40-36 per cent of the in laws were supporting them for time management were appreciating for their work efficiency. However 38 per cent of the in laws were complaining about inconvenience of family members due to employment of daughter in law. 
In case of unemployed mothers experiences regarding support they get at home, their husbands were sharing family responsibilities (100\%) but 85 per cent of them were not at all helping in household chores and 64 per cent of the unemployed mothers expressed that they feel being neglected by their husbands or family members. Nearly 50 per cent of the in laws of unemployed mothers support in managing homes as well as in managing time while they also reported that they do not get help of in laws for any of the household chores.

The highly significant $Z$ values indicate the differences in employed and unemployed mothers experiences regarding support from the family members they receive with respect to managing home while husbands were cooperative in supporting employed mothers in time management, appreciating their work efficiency and were valued by in laws in decision making in family matters, children's education etc.

While husbands as well as in laws were complaining about inconvenience of family members, conflict occurring in family due to employment or unemployment of women, no help was rendered by family in household chores, inadequacy in family expenses due to

Insufficient income, being neglected by the family members.

The research study of Biernat, $M$. and Wortman, C, B.(1991) are in line with the above results.

Table 6 denotes correlation between adoption of disciplinary practices for children by the mothers and their selected background variables. The gender, school timings and medium of education of the children and disciplinary practices followed by the employed mothers were found to be positively correlated. It was seen that the children who were attending school in afternoon, in spite of employed mother office schedules, they were involved in disciplining their children. It was also seen that as the hours of employment of the mothers were increasing their involvement in child disciplinary practices were increasing significantly.

There was a positive correlation between the age of children and SES of family with the disciplinary practices followed by the unemployed mothers. Whereas negative correlation was found between, maternal age and adopted disciplinary practices by the unemployed mothers indicating with increased age the mothers were neglecting towards the discipline of the children.

\section{References}

Aeri, P., and Jain, D. 2010. Effect of employment status of mothers on conceptual skills of prescholars. Journal of Social Sciences. 24(3), 213215.

Alizadeh, S., 2011. Relationship between Parenting Style and Children's Behavior Problems. Journal Asian Social Science. 7(12), 195-200.

Anil, M. A., Bindu, S and Bhat, J. S. 2021. Analysis of employed and unemployed mother's perspectives towards story narration in typically developing children. Bangladesh Journal of Medical Science. 20(1), 86-94.

Baumrind, D., 1971. Parenting styles and adolescent development. In BrooksGunn, J., Lerner, R., and Peterson, A. C. (Eds.), The Encyclopedia of Adolescence, Garland, New York, pp. 746-758.

Baumrind, D., 1991. Effective parenting during the early adolescent transition. In P. A. Cowan \& E. M. Hetherington (Eds.) Family transitions. Advances in 
family research series. Hillsdale, NJ, England: Lawrence Erlbaum Associates, Inc.

Baydar, N and Gunn, J. B. 1991. Effects of maternal employment and child-care arrangements on preschoolers' cognitive and behavioral outcomes: evidence from the children of the national longitudinal survey of abuth. Journal Developmental Psychology. 27(6): 932-945.

Biernat, M. and Wortman, C, B. 1991. Sharing of home responsibilities between professionally employed women and their husbands. Journal of personality and social psychology. 60(6): 844-860.

Craige, L., 2006. Parental education, time in paid work and time with children: an Australian time-dairy analysis. The British Journal of Sociology. 57 (4): 553-575.

Dixit, K., 2007. A study of personality, adjustment level and family relationship of children of employed and unemployed mothers (Doctoral Dissertation). Bundelkhand University, Jhansi. Retrieved from http://hdl.handle.net/10603/11014. Accessed on September 11, 2013.

Gold, D., and Andres, D. 1978. Developmental comparisons between ten year old children with employed and non employed mothers. Child Development, 49(1): 75-84.
Harries, S., 2018 Maternal employment and child development. Undergraduate Honors Theses. 1725. https://scholar.colorado.edu/honr_these s/1725. 3-28.

Lee, J., Katras, M. J \&. Bauer, J. W. 2009 Children's Birthday Celebrations From the Lived Experiences of Low-Income Rural Mothers. Journal of Family Issues. 30(4): 532-553.

Mayuri, K., Divya, V \& Kiran, K. 2017. Parenting style as perceived by perceived by parents and children. International Jr. of Science and Research. 6(8): 978-982.

McWayne, C., Hampton, V., Fantuzzo, J., Cohen, H. L. \& Sekino, Y. 2004. A multivariate examination of parent involvement and the social and academic competencies of urban kindergarten children. Psychology in the Schools, 41(3): 363-377.

Saini, S. 2005. Family environment and academic achievement of adolescent children of working and nonworking mothers. Indian educational review, 41(2): 87-95.

Sultana, A. M \& Noor, Z. 2012. Mothers' Perception on the Impact of Employment on their Children: Working and Non-working Mothers. International Journal of Social Science. 2(1): 113-129.

\section{How to cite this article:}

Bhalerao, V. S. and Ujagare, P. N. 2021. Maternal Employment Status and Influence of Parenting Practices on Children. Int.J.Curr.Microbiol.App.Sci. 10(08): 368-378. doi: https://doi.org/10.20546/ijcmas.2021.1008.045 